\title{
Delito de abandono de PERSONAS DESVALIDAS
}

[Crime of Abandonment of Helpless Persons]

\author{
Javiera TORRES SANDOVAL*
}

\begin{abstract}
RESUMEN
El trabajo analiza el delito de abandono de personas desvalidas tipificado en el artículo $352 \mathrm{CPen}$. En particular, aborda la historia de su tipificación, las opiniones de la doctrina comparada, los elementos del tipo -en especial la problemática que suscita la muerte y lesiones como exigencia legal-y las eventuales relaciones concursales con los delitos de homicidio, lesiones y abandono de menores.
\end{abstract}

\section{Palabras Clave}

Abandono de personas - Condiciones objetivas de punibilidad - Relaciones concursales.

\begin{abstract}
This work analyses the crime of abandonment of helpless persons, specified in article 352 of the Criminal Code. It specifically, addresses the process by which it was specified, the opinions of compared doctrine, the elements of the kind of offence -specially the issue arising from the death and injuries as legal requirementand the eventual relationships that played a part in the crimes of homicide, injuries and abandonment of minors.

\section{KEYWORDS}

abandonment of people - Objective conditions of punishment - Relationships playing a role in the event.
\end{abstract}

RECIBIDo el 1 de septiembre y ACEPTADo el 22 de diciembre de 2014

\footnotetext{
*Correo electrónico: javiera.torres.sandoval@gmail.com
} 


\section{INTRODUCCIÓN}

El delito de abandono de personas desvalidas está tipificado en el artículo 352 CPen. que sanciona: "El que abandonare a su cónyuge o a un ascendiente o descendiente, legitimo o ilegitimo, enfermo o imposibilitado, si el abandonado sufriere lesiones graves o muriere a consecuencia del abandono, será castigado con presidio mayor en su grado minimo".

Delito que plantea diversas interrogantes relativas al bien jurídico protegido, la conducta típica, las formas de comisión, la exigencia de un elemento que puede ser considerado como elemento del tipo o condición objetiva de punibilidad, la clasificación del mismo según las categorías tradicionales del derecho penal y las eventuales relaciones concursales con delitos como el homicidio, lesiones y abandono de menores. Interrogantes que se intentarán resolver teniendo en consideración tanto la historia de la tipificación de este delito como figuras análogas existentes en el derecho comparado, atendiendo principalmente el hecho de que estas discusiones en general no han sido tratadas por nuestra doctrina, de forma que no existe un análisis detallado del mismo y por ello será el objeto a abordar.

\section{NOTAS SOBRE LA EVOLUCIÓN HISTÓRICA DE SU TIPIFICACIÓN}

El artículo 352 acompaña al Código Penal chileno desde sus orígenes, es decir, desde el proyecto de 1874 . Esto lo podemos afirmar ya que tal disposición tiene su génesis en la sesión 67 de la Comisión Redactora, realizada con fecha 2 de diciembre de 1871, en la cual don Alejandro Reyes (presidente de la misma) pidió que se completaran las disposiciones sobre abandono de niños por sus padres "agregando el caso en que un hijo abandone a su padre desvalido; pero en atención a que es difícil que tal caso ocurra, $i$ un hecho semejante no podría caracterizarse como delito tan bien como el abandono de un hijo por su padre, se resolvió no hacer la agregación solicitada". A pesar de ello, dicha solicitud dio pie para que en la sesión 159 de 24 de junio de 1873, el señor Reyes volviera a manifestar la necesidad de "tomar en cuenta una especie de delitos que puede ocurrir, el abandono de enfermos o desvalidos por los parientes a cuyo cuidado se hallan, siempre que de ello resulte grave daño. Citó con tal efecto ejemplos prácticos de tales abandonos, en que no se niega un simple deber de caridad, sino que se viola una obligación perfecta $o$ inexcusable"2. Y, para que pudiera darse cabida a tal disposición en el párrafo

\footnotetext{
${ }^{1}$ Rivacoba, Manuel de, Código Penal de la República de Chile y actas de las sesiones de la comisión redactora (Valparaíso, EDEVAL, 1974), p. 380.

${ }^{2}$ Ibíd., p. 534.
} 
correspondiente se cambió el epígrafe a: "Del abandono de niños i personas desvalidas". Aprobándose como artículo 355 el siguiente: "El que abandonare a su cónyuge o a un ascendiente lejitimo o natural, enfermo o imposibilitado, $i$ el paciente sufriere lesión grave o incurriere a consecuencia del abandono, será castigado con presidio menor en su grado minimo"3.

Con posterioridad, el 17 de octubre de 1873, en la sesión 173, se cambió la redacción de dicho artículo, sustituyéndola por: "El que abandonare a su cónyuge o a un ascendiente o descendiente lejitimo o ilejítimo, enfermo o imposibilitado, será castigado con presidio mayor en su grado minimo, si el abandonado sufriere lesiones graves o muriere a consecuencia del abandono" ${ }^{\text {. }}$.

Respecto al origen del artículo 352, si bien la doctrina afirma ${ }^{5}$ que nuestro título $7^{\circ}$ del libro II tendría su fuente en el Código Penal belga, en particular respecto del delito en estudio ello no es así. Demuestra lo anterior que en la tabla de concordancias del Código elaborada por Pedro Javier Fernández ${ }^{6}$ tal delito no tiene señalado como fuente directa algún artículo del Código Penal español o belga, lo que daría cuenta de que sería una creación de la Comisión Redactora. Por lo demás, analizando el Código Penal del Reino de Béljica de $1867^{7}$, en el capítulo $2^{\circ}$, título $7^{\circ}$, libro II, sólo se incluyen figuras referidas a la exposición o abandono de niños, y no así de personas adultas.

Figura que tampoco existe en la versión actual del Código Penal belga, ya que en el capítulo $3^{\circ}$ del título $8^{\circ}$ del libro II, nos encontramos sólo con tipos penales que sancionan el descuido y abandono de niños o incapaces (artículo 423), la privación de alimentos o cuidados impuestos a menores o incapaces (artículo 425), y el artículo $426^{8}$ que sanciona a quien teniendo la custodia de un menor o persona que no puede mantenerse en razón de su

${ }^{3}$ Ibíd., p. 534.

${ }^{4}$ Ibíd., p. 558.

${ }^{5}$ Cfr. Politoff, Sergio - Grisolía, Francisco - Bustos Ramírez, Juan, Derecho penal chileno. Parte especial. Delitos contra el individuo en sus condiciones fisicas (2a edición, Santiago, Editorial Jurídica de Chile, 2001), p. 265.

${ }^{6}$ Fernández, Pedro Javier, Código Penal de la República de Chile esplicado i anotado (Santiago, Imprenta de la Librería del Mercurio, 1875).

${ }^{7}$ Código Penal del Reino de Béljica (Santiago, Imprenta Nacional, 1868).

${ }^{8}$ "Sera puni d'un emprisonnement de huit jours à deux mois et d' une amende de cinquante [euros] à cinq cents [euros] ou d'une de ces peines seulement, sans préjudice, s'ily a lieu, de lapplication de dispositions pénales plus sévères, quiconque ayant la garde d'un mineur ou d'une personne hors d'état de pourvoir à son entretien en raison de son état physique ou mental, aura négligé lentretien de ce mineur ou de cette personne au point de compromettre sa santé. $\$ 2$. Si les négligences ont entraîné la mort du mineur ou de la personne hors d'état de pourvoir à son entretien en raison de son état physique ou mental, le coupable sera puni d'un emprisonnement de trois mois à deux ans et d'une amende de cinquante [euros] à mille [euros]”. 
estado físico o mental, haya descuidado a la víctima, con peligro a su salud, o bien le ocasionare la muerte. Previéndose una agravación por parentesco en el artículo $427^{\circ}$. Si bien esta disposición es la que más se asemeja a nuestro artículo 352, no abarca las mismas hipótesis, ya que en primer lugar, no realiza exigencia alguna respecto del sujeto activo en su figura básica, y en segundo lugar, porque para sancionar tal conducta bastaría con el peligro a la salud a que se expone a la víctima, hipótesis inexistente en nuestro ordenamiento jurídico si consideramos que las lesiones o muerte que exige el artículo 352 son condiciones objetivas de punibilidad. Si bien, respecto al resultado muerte podríamos encontrar un aspecto en común, ello debe hacerse teniendo siempre presente la discusión que en nuestra doctrina se da respecto a tal elemento.

Por eso coincidimos con aquella opinión que sostiene que el artículo 352 habría sido aprobado como "un corolario de estos preceptos en base a que al abandonar a los familiares enumerados no se viola un deber de caridad, sino una obligación perfecta e inexcusable"10.

\section{TRATAMIENTO DEL DELITO SEGÚN LA DOCTRINA COMPARADA}

\section{España.}

El Código Penal español (aprobado por la Ley Orgánica 10/1995, de 23 de noviembre de 1995) no contiene una figura idéntica a nuestro artículo 352. Sin embargo, dentro de las figuras más próximas al mismo podemos destacar el artículo 226, disposición ubicada en la sección $3^{\text {a }}$ del capítulo $3^{\circ}$, título $12^{\circ}$ del libro II "Del abandono de familia, menores o incapaces" y que tipifica las siguientes conductas: "1. El que dejare de cumplir los deberes legales de asistencia inherentes a la patria potestad, tutela, guarda o acogimiento familiar o de prestar la asistencia necesaria legalmente establecida para el sustento de sus descendientes, ascendientes o cónyuge, que se hallen necesitados, será castigado con la pena de prisión de tres a seis meses o multa de seis a 12 meses. 2. El Juez o Tribunal podrá imponer, motivadamente, al reo la pena de

9 "Dans les cas prévus aux articles 423, 425 et 426, si le coupable a commis les faits envers ses père, mère, adoptants ou autres ascendants, le minimum de la peine portée par ces articles sera doublé s'il s'agit d'un emprisonnement, et augmenté de deux ans s'il s'agit de la réclusion. Il en sera de même lorsque le coupable est le père, la mère ou l adoptant de la victime, ou toute autre personne ayant autorité sur elle ou ayant sa garde".

${ }^{10}$ Sepúlveda, María Eugenia, Las relaciones de familia y su influencia en la responsabilidad penal (memoria de prueba para optar al grado de licenciado en la Facultad de Ciencias Jurídicas, Políticas y Sociales de la Universidad Católica de Chile, 1966), p. 30. 
inhabilitación especial para el ejercicio del derecho de patria potestad, tutela, guarda o acogimiento familiar por tiempo de cuatro a diez años".

$\mathrm{Al}$ respecto se ha afirmado ${ }^{11}$ que este sería un delito de aplicación ocasional, a diferencia de otras figuras ubicadas en la misma sección $3^{\text {a }}$, como lo son los artículos 227 (impago de pensiones) y 232 (utilización de menores o incapaces para la mendicidad). Con todo, el artículo 226 comparte con dichas figuras el que "pretende asegurar el cumplimiento de aquellas obligaciones que tienen como fin garantizar el bienestar de los menores y otros miembros de la familia"12.

En relación con el bien jurídico protegido, este sería la seguridad ${ }^{13}$, en el sentido de seguridad material que se deriva de las relaciones familiares. En efecto, Muñoz Conde afirma que ésta implicaría "la ausencia de peligro, pero como es imposible, debe ser entendida como la expectativa jurídicamente fundada que puede tener toda persona de ser ayudada por sus familiares obligados a ello en el caso que así lo necesite, o por lo menos, de no ser puesto en situación de peligro por sus familiares" ${ }^{\prime 14}$.

Respecto a la conducta típica, esta admitiría dos formas de comisión, ambas omisivas, el incumplimiento de cualquiera de los deberes asistenciales respecto de menores o incapaces sometidos a tutela, patria potestad, guarda $\mathrm{o}$ acogimiento familiar, o bien, el incumplimiento de la obligación de proporcionar la asistencia necesaria para el sustento respecto de los descendientes mayores de edad capaces y emancipados, de los ascendientes y del cónyuge.

Como es la segunda hipótesis la que podría asimilarse más a nuestro delito de abandono de personas desvalidas, es que procederemos a efectuar un somero análisis de la misma. Con todo, es necesario hacer la prevención de que el artículo 226 se constituye como una ley penal en blanco impropia puesto que debe integrarse normativamente con las disposiciones del Código Civil español, el que establece cuáles son los distintos deberes de asistencia inherentes a los eventuales sujetos activos del tipo penal.

En primer lugar, consiste en un delito de omisión propia, puesto que se

${ }^{11}$ Castiñeira Palou, María Teresa, Tema 9. Delitos contra las relaciones familiares, en Silva Sánchez, Jesús María (director), Lecciones de derecho penal. Parte especial (Barcelona, Atelier, 2006), p. 170.

${ }^{12}$ Ibíd., p. 170.

${ }^{13}$ Sin perjuicio de existir otras posturas; por ejemplo, la de Gómez tomillo, Manuel, Protección jurídico penal de las personas mayores frente al abandono, especial consideración de los delitos de los Arts. 226, 229, 230, de la falta del artículo 619 CP y de sus relaciones concursales, en Revista de Derecho penal y Criminología $3^{a}$ época, 4 (2010), pp. 175-198, quien sostiene que el bien jurídico tutelado es la dignidad, integridad física y moral de la persona.

${ }^{14}$ Muñoz Conde, Francisco, Derecho penal. Parte especial (16a edición, Valencia, Tirant Lo Blanch, 2007), p. 311. 
sanciona el no prestar la asistencia debida, sin exigir la producción de algún resultado que pudiere afectar por ejemplo la vida o salud del sujeto pasivo, ya que el delito se consuma "cuando la omisión ha provocado una real situación de inseguridad para el sujeto pasivo"15 , que en esta forma de comisión se deduciría de la exigencia típica de que dichas personas se hallen necesitadas.

En segundo lugar, que "probablemente estemos ante un delito de los que la doctrina denomina de peligro hipotético o de aptitud abstracta; (ya que) se requiere la idoneidad de la conducta para poner en peligro o lesionar el bien jurídico"16. Se agrega además, que "es un delito permanente de omisión que se perpetra de manera ininterrumpida mientras el culpable persista en el abandono familiar, de manera que sus efectos duran mientras persista la situación de incumplimiento" ${ }^{17}$. Se trataría por tanto, de un delito permanente.

Ahora, para determinar qué debe entenderse por la obligación de prestar sustento "resulta imprescindible la cita del artículo 142 CCEsp. que regula el deber de alimentos entre parientes que abarca 'todo lo que es indispensable para el sustento, habitación, vestido y asistencia médica'. De lo expresado se deduce que sólo se protege jurídico penalmente el deber de prestar sustento" 18 .

Dadas tales características, se han estimado como típicas ${ }^{19}$ conductas como la del padre que se marcha de casa para vivir con otra mujer no teniendo contacto alguno con sus hijos, a los que tampoco facilitaba dinero para subsistir, así como la del padre que abandona el domicilio dejando totalmente inasistidos a su esposa e hijos, hasta el punto de que perdieron la vivienda. Sin embargo, como la doctrina entiende que "la conducta nuclear consiste en el incumplimiento de los más elementales deberes de asistencia que no se circunscriben exclusivamente a lo estrictamente material, económico o alimenticio, a la muy esencial contribución al levantamiento de las cargas familiares, sino que se extiende a los demás deberes asistenciales, como son los de velar por esas personas, cuidarlas y protegerlas, proporcionarles asistencia sanitaria, instruirles en una formación integral, cultural, social, moral, etc." ${ }^{20}$, creemos que sí puede asimilarse a la conducta típica (en sentido estricto, sin considerar la discusión acerca de las lesiones o muerte) de nuestro artículo 352 , es decir, el abandonar al cónyuge o a un ascendiente o descendiente.

${ }^{15}$ Martínez Guerra, Amparo, Sección 3a. Del abandono de familia, menores o incapaces, en Rodríguez Ramos, Luis (director), Código Penal comentado y con jurisprudencia ( $3^{\text {a }}$ edición, Madrid, La Ley, 2009), p. 756.

${ }^{16}$ Gómez Tomillo, M., cit. (n. 13), pp. 175-198.

${ }^{17}$ Ibíd., pp. 175-198.

${ }^{18}$ Ibíd., pp. 175-198.

${ }^{19}$ Martínez Guerra, A., cit. (n. 15), p. 753.

${ }^{20}$ Ibíd., p. 742. 
Sin embargo, aquí no se exige ninguna consecuencia lesiva a la vida o salud de la víctima, puesto que la exigencia de que la víctima se halle necesitada es anterior a la conducta típica, y no es causada por ella, por lo que estaría tipificando una conducta previa a la efectiva lesión de los derechos del sujeto pasivo, sancionando simplemente el omitir prestar la asistencia necesaria. $\mathrm{Y}$ es dicha consideración la que podría ser la causa de la escasa aplicación práctica de la figura del artículo 226, ya que de causarse algún resultado como podrían ser las lesiones o muerte (como lo exige nuestro Código Penal), tendrá aplicación preferente el respectivo delito contra la salud o vida del sujeto pasivo (siempre y cuando el resultado sea abarcado por el dolo del autor, aun eventual).

Con todo, si se sigue una postura distinta acerca del bien jurídico tutelado, como lo sería la dignidad e integridad física y moral de la persona ${ }^{21}$, de ello se desprendería que "en los casos en los que el resultado lesivo sobrevenga asociado al abandono procede apreciar un concurso de delitos, puesto que la dignidad de la personas no es equivalente a la suma de vida, salud, libertad y otros derechos del individuo, sino que siempre queda un remanente que puede ser menoscabado, aunque no se afecte a tales derechos" ${ }^{22}$. Concurso que a nuestro entender sería un concurso ideal y que permitiría afirmar con mayor fuerza la idea de que se trataría de una figura que permitiría subsumir la conducta típica (pero sólo ésta) de nuestro artículo 352 (el abandonar) quedando por resolver la consideración acerca de las eventuales lesiones y muerte; que en nuestro caso, y en principio, sería una condición objetiva de punibilidad (no integradora de la conducta típica) y en el caso español, constitutiva de un delito distinto, en concurso ideal.

\section{Argentina.}

El Código Penal argentino contiene en su capítulo $6^{\circ}$, título $1^{\circ}$, libro II "Abandono de personas" el artículo 106 que sanciona: "El que pusiere en peligro la vida o la salud de otro, sea colocándolo en situación de desamparo, sea abandonando a su suerte a una persona incapaz de valerse y a la que deba mantener o cuidar o a la que el mismo autor haya incapacitado, será reprimido con prisión de 2 a 6 años".

Dicha disposición, como ya señalamos, se encuentra ubicada en el título relativo a los delitos contra las personas, y se trataría de un delito en que la acción típica "no es simplemente abandonar o colocar en situación de desamparo al sujeto pasivo, sino la de poner en peligro su vida o salud mediante

\footnotetext{
${ }^{21}$ Cfr. Gómez Tomillo, M., cit. (n. 13), pp. 175-198.

${ }^{22}$ Martínez Guerra, A., cit. (n. 15), p. 197.
} 
el abandono o su colocación en situación de desamparo"23, momento en el cual se consuma. Es un delito que se configura como una figura de peligro, que sólo se convierte en un delito de lesión para la vida y salud del sujeto pasivo en sus figuras agravadas, como ya veremos.

Respecto a la conducta típica, el artículo 106 prevé tres, las que tienen en común la exigencia de que mediante estas formas de comisión resulte un peligro para la vida o salud de la víctima:

i) Colocar a una persona en situación de desamparo. $\mathrm{Al}$ respecto no se formula exigencia acerca de la especial forma de comisión, ni sobre los sujetos activo y pasivo, por lo que se trataría de un tipo de sujeto indiferente, pero sí se exige que la persona sea colocada en una situación de desamparo. Al respecto Creus afirma que "se coloca a la víctima en situación de desamparo cuando el agente la rodea de circunstancias que le obstaculizan o impiden obtener los auxilios que exige su condición, lo cual puede ocurrir por el traslado de la víctima a un lugar donde la prestación de esos auxilios se torna imposible (por ejemplo a un sitio deshabitado), por su aislamiento de las comunicaciones necesarias (por ejemplo privándola de medios de comunicación), o preservando el mantenimiento de esas condiciones, vigilando su cumplimiento (por ejemplo cuidando que se mantenga el encierro sin auxilio)"24.

ii) Abandonar a su suerte a una persona incapaz de valerse y a la que el autor debe mantener o cuidar. Esta segunda hipótesis se diferencia de la anterior, en que puede cometerse tanto por acción como por omisión (impropia) y en que el sujeto activo sólo puede ser quien tiene el deber de mantener o cuidar a dicha persona incapaz. Esta obligación puede provenir de las fuentes tradicionales (ley, negocio jurídico o actuar precedente). Respecto del sujeto pasivo, tampoco puede ser cualquiera, sino que aquel incapaz de valerse por sí mismo, es decir, "quien carece de aptitud para proveerse a sí misma" 25 . Persona incapaz que puede ser tanto un menor de diez años, como quien se halla incapacitado por causa enfermedad ${ }^{26}$. Por último, respecto a esta segunda forma de comisión, se ha sostenido que "se abandona a la víctima cuando se la deja privada de los auxilios o cuidados que le son imprescindibles para mantener su vida o la integridad actual de su salud, cuando ella misma

${ }^{23}$ Creus, Carlos, Derecho penal. Parte especial (6a edición, Buenos Aires, Astrea, 1997), I, p. 114.

${ }^{24}$ Creus, Carlos, cit. (n. 23), pp. 114-115.

${ }^{25}$ Fontán Balestra, Carlos, Tratado de derecho penal. Parte especial (Buenos Aires, Abeledo Perrot, 1969), p. 354, cit. por Buompadre, Jorge, Derecho penal. Parte especial (2a edición, Buenos Aires, Mario A. Viera, 2003), p. 265.

${ }^{26}$ Cfr. Buompadre, Jorge, cit. (n. 25), p. 265. 
no puede suministrárselos y en situación en que normalmente no es posible que se los presten los terceros (abandonar a su suerte)"27.

iii) Abandono de la persona a quien el autor ha incapacitado. Se trata también de un delito especial, puesto que únicamente puede cometerlo quien tiene el deber de garante del bien jurídico tutelado por la ley. Incapacidad que no es causa del abandono, sino que es una situación previa a ésta, causada también por el autor, ya sea dolosa o culposamente ${ }^{28}$. El ejemplo clásico lo constituye el caso de quien causa un accidente y abandona al lesionado sin socorrerlo. A pesar de ello, "se ha considerado que no configura delito cuando la víctima, incapacitada por el autor, puede ser socorrida por terceros de acuerdo con las circunstancias de lugar y tiempo del hecho"29.

Acto seguido los párrafos segundo y tercero tipifican figuras agravadas de este tipo básico: "La pena será de reclusión o prisión de 3 a 10 años, si a consecuencia del abandono resultare grave daño en el cuerpo o en la salud de la victima./ Si ocurriere la muerte, la pena será de 5 a 15 años de reclusión o prisión".

En primer lugar, el concepto de grave daño ha generado discusión en la doctrina argentina, puesto que para algunos sólo comprendería lesiones graves y gravísimas (de los artículos 90 y 91), en tanto que para otros, bastaría con que el cuerpo o salud de la víctima sufran un perjuicio importante aunque no configure los tipos ya señalados ${ }^{30}$.

Con todo, tanto respecto del grave daño como de la muerte del sujeto pasivo, la doctrina entiende que consistirían en figuras preterintencionales, que procedan causalmente de la situación de desamparo en que se colocó a la víctima o abandono. En ello podemos apreciar una radical diferencia con nuestra situación particular del artículo 352, respecto del cual se discute si la muerte o lesiones graves que sufre el abandonado son efectivamente resultados típicos o bien una condición objetiva de punibilidad. Discusión en la que al parecer prima esta última postura.

Respecto a su aplicación práctica, esta disposición ha recibido una especial consideración por parte de aquella postura doctrinal que considera, ante la ausencia de una cláusula general de comisión por omisión, vinculado además a la configuración del delito de homicidio como una conducta activa, que en casos como los que procederemos a mencionar, se proponga la aplicación del artículo 106. Postura que si bien sería minoritaria, "no genera lagunas

${ }^{27}$ Creus, Carlos, cit. (n. 23), p. 114.

${ }^{28}$ Con todo, existen posturas diferentes. Véase: Iellin, Dalia - PACheco y Miño, Julio, Capitulo VI. Abandono de personas, en D’Alessio, Andrés José (director), Código Penal comentado y anotado. Parte especial (Buenos Aires, La Ley, 2004), p. 96.

${ }^{29}$ Iellin, D. - Pacheco y MiÑo, J., cit. (n. 28), p. 96.

${ }^{30}$ Cfr. Creus, C., cit. (n. 23), p. 117. 
de punición intolerables" ${ }^{11}$. En consecuencia y para tal postura, ello "refleja la imposibilidad de estimar, a través del Código Penal argentino vigente, que una conducta omisiva estricta, aun direccionada a conseguir que otra persona muera, sea imputable por vía de un tipo de causación. Tal opción vulnera (según el parecer de Soria) el principio de legalidad desde, al menos, dos flancos: i) por violación a la lex scripta, en tanto el deber de garante no se encuentra previsto en la ley y, su sostenimiento, provendría, así del derecho consuetudinario; ii) Por conculcar la lex stricta, pues responde a una interpretación analógica in malam partem -vedada- del tipo, en razón de que la posición de garante no es un elemento del tipo objetivo de los homicidios dolosos de nuestro Código Penal'32.

Para ilustrar la postura señalada, Soria cita casos conocidos por la jurisprudencia argentina, entre ellos, el caso Cabral consistente en la conducta de una madre respecto de su hijo de nueve meses a quien no defendió de las agresiones de su pareja, las que finalmente le causaron la muerte. Agrega que "en dicho decisorio, a través del destacado voto del Dr. Ghione, se sostuvo que la condena de Cabral como autora de homicidio agravado por el vínculo (artículo 107) no era sostenible desde el principio de legalidad, pues la acusada no había matado, sino que, por el contrario, en conocimiento del riesgo de muerte de su hijo por parte de las agresiones de su concubino, dejó que ello se mantuviera así, en franca confrontación al deber previsto en artículo 264 incisos $2^{\circ}$ y $4^{\circ}$ del Cód. Civil. Con tal actitud (omisión), puso en peligro la vida de su hijo, abandonándolo a su suerte y resultando de ello su muerte"33. Acusada que fue condenada como autora del delito de abandono de personas, en su modalidad calificada, del párrafo $3^{\circ}$ del artículo 106 y artículo 107.

Misma solución se observó en el caso Alférez ${ }^{34}$, respecto de la omisión del padre de impedir el comportamiento homicida de su pareja, el que tuvo como consecuencia la muerte por traumatismo craneal de su hija. Fallo en el que "además de destacarse la ausencia de la cláusula general de comisión por omisión en (el) ordenamiento (argentino), circunstancia que impide sostener el homicidio de esa clase por vía del artículo 79 CPen., se descartó la posibilidad de coautoría por omisión" 35 .

Por último, respecto de aquellos casos de homicidio por omisión donde hay un único autor, por ejemplo, el caso de la madre que deja morir a su hijo por inanición, afirma Soria que también podrían sancionarse acudiendo a la

\footnotetext{
${ }^{31}$ Soria, Juan Manuel, La omisión en el sistema penal. Relación entre las figuras de homicidio y abandono de personas (Buenos Aires, Cathedra Jurídica, 2009), p. 142.

${ }^{32}$ Soria, J. M., cit. (n. 31), p. 140.

${ }^{33}$ Ibíd., pp. 145-146.

${ }^{34}$ Ibíd., p. 147.

${ }^{35}$ Ibíd., p. 147.
} 
figura de abandono de personas. Para sostenerlo recurre como argumento a la ubicación de tal disposición en el Código Penal argentino (delitos contra las personas), así como las diversas modificaciones que ha sufrido la disposición. A saber, la ampliación del sujeto pasivo (de niños a cualquier persona), el traslado a este título, ya que antes se encontraba en el correspondiente a "Delitos contra las garantías individuales", así como la inclusión del deber de auxilio por injerencia y el aumento de las escalas penales. Ello le permite sostener que "su principal fuente teleológica se ha visto evidentemente ampliada, con la evidente posibilidad de apreciar, hoy en día, diversas hipótesis de abandono en el marco de una mixtura abierta de conflictos sociales. Y dentro de este grupo no considero desacertado ubicar casos omisivos en sentido estricto, penalmente relevantes en relación con la vida e integridad física de las personas" ${ }^{\prime 36}$.

En conclusión, el Código Penal argentino, y en particular a partir de la postura analizada precedentemente, permite sostener que se sanciona la misma conducta que tipifica nuestro artículo 352. Con todo, podemos volver a hacer la diferencia respecto del resultado de lesiones o muerte del sujeto pasivo, que en el caso argentino son constitutivos de circunstancias que agravan la responsabilidad (delito agravado por el resultado) y que según la doctrina ya examinada se configuran como figuras preterintencionales, donde el autor al menos debe haber previsto su posibilidad, aun cuando la rechazare. Pero por otro lado, son mayores las formas de comisión que se prevén en el artículo 106, así como las exigencias respecto de los sujetos activo y pasivo en sus tres conductas típicas, y sólo como circunstancia agravante se considera, de manera general, la concurrencia de un especial vínculo, puesto que el artículo 107 señala que "El máximum y el mínimum de las penas establecidas en el articulo precedente, serán aumentados en un tercio cuando el delito fuera cometido por los padres contra sus hijos y por éstos contra aquéllos o por el cónyuge".

\section{Alemania.}

El $₫ 221$ Strafgesetzbuch sobre exposición y abandono de personas se ubica en la sección decimosexta relativa a hechos punibles contra la vida y sanciona determinadas conductas que conducen a poner en peligro la vida e integridad corporal de ciertas personas. En particular, sanciona ${ }^{37}$ a "Quien ponga a una persona en situación de desamparo, o la abandone en situación

${ }^{36}$ Ibíd., p. 152.

${ }^{37}$ Strafgesetzbuch, 1998 (traducción de Claudia López Díaz, Bogotá, Universidad Externado de Colombia, 1999). En cursiva: modificaciones de la versión actual StGB, visible en internet: http://www.gesetze-im-internet.de/englisch_stgb/englisch_stgb. html - StGBengl_000P221 
de desamparo aunque esté bajo su custodia o esté obligado de otra manera para asistirle y la exponga de esta forma al peligro de muerte o a un grave perjuicio de salud, será castigado con pena privativa de la libertad de tres meses hasta cinco años".

Modalidad básica que constituiría un delito de peligro, señalando a continuación sus $\$ \$ 2$ y 3 agravaciones para aquellos casos en que se produzca una lesión corporal o la muerte del sujeto pasivo, bajo la modalidad de un delito preterintencional. En concreto, en tales párrafos se prescribe: "La pena privativa de la libertad será de uno a diez años cuando el autor cometa el hecho contra su hijo o una persona que le es encomendada para la educación o formación o, le cause un grave perjuicio de salud a la víctima a causa del hecho.

Si el autor causa la muerte de la víctima a través del hecho, entonces la pena (será) privativa de la libertad no inferior a tres años.

$\$ 4$ agrega: “En casos menos graves del inciso II se impondrá pena privativa de la libertad de seis meses a cinco años; en casos menos graves del inciso III se impondrá pena privativa de la libertad de un año hasta diez años".

Luego, las conductas típicas de la modalidad básica son dos, las que tienen en común que "tienen que poner a la víctima en una situación de desamparo o bien dejarla en esa situación"38. Al respecto se ha afirmado que la víctima se halla en tal circunstancia cuando "no puede aventar por sí misma un peligro grave para su vida -y, según la opinión dominante, también para su salud-" 39 . $\mathrm{Y}$ es producto de tal exigencia que la doctrina alemana califica este delito como de peligro concreto.

En particular la primera forma de comisión, que no contiene exigencia alguna referida al sujeto pasivo, consiste en poner a una persona en situación de desamparo ${ }^{40}$ lo que ha sido entendido por la doctrina como la exposición, el traslado de la víctima de un lugar a otro, lo que sucede "las más de las veces, llevando el autor mismo a la víctima a otro lugar. Pero la variación del lugar se convierte en exposición recién cuando están cumplidos otros dos presupuestos: (cuando) se le sustrae a la víctima la ayuda ajena (o bien

${ }^{38}$ STRUENSEE, Eberhard, Exposición y abandono de personas, en JAKOBS, Günther - Struensee, Eberhard, Problemas capitales del derecho penal moderno ("Prólogo" y "Presentación” de Marcelo A. Sancinetti, Buenos Aires, Hammurabi, 1998), p. 84.

${ }^{39}$ STruensee, E., cit. (n. 38), p. 84.

${ }^{40}$ Exigencia que si bien no siempre tuvo consagración legal de todas formas era concluida por la doctrina. Así por ejemplo STRUenSeE, E., cit. (n. 38), p. 85, para quien "en el contenido de ilicitud y de culpabilidad la ley equipara la exposición (por parte de un no garante) con el abandono (por parte de un garante). De allí se deriva que, valorativamente, también la punibilidad de la exposición exige asimismo una puesta en peligro concreto, igual que a la del abandono". 
de otra protección subsistente), y ella entra por esa vía en una situación de desamparo" ${ }^{\prime 1}$. De esta manera, el delito se consuma una vez producida la variación de lugar en que se encontraba la víctima y cuando ello conduce a que ésta entre en grave situación de necesidad sin recibir ayuda alguna.

La segunda forma de comisión "consiste en que el autor-que tiene que ser garante al ejecutar la acción del hecho ('obligado a la custodia') -se aleje de la persona necesitada de auxilio. Pero tampoco aquí basta la mera separación temporal entre autor y víctima; más bien el autor tiene que dejar a la víctima 'en situación de desamparo"'‘2. Lo que permite configurarlo también como una figura de peligro concreto. $\mathrm{Al}$ respecto se discute si se puede subsumir en el tipo el omitir volver a tiempo bajo la idea de abandonar. Por ejemplo, la madre que deja en casa a su hijo pequeño mientras va a comprar por una o dos horas. Struensee ${ }^{43}$ rechaza tal posibilidad, pero reconoce que la jurisprudencia y opinión dominante lo permiten. Y agrega que estas dificultades se evitan si, "para el tipo objetivo, basta con que la persona desamparada o bien ya se encuentre en el momento del abandono en situación de necesidad grave, o bien que entre en grave necesidad después de él”“4 .

Por último, en este caso sí se formula una exigencia respecto del sujeto activo, ya que sólo puede cometerlo quien esté en posición de garante de la vida o salud de la víctima, ya sea porque la víctima esté bajo su custodia o bien, el autor esté obligado de otra manera a ella (pudiendo acá tener cabida las demás fuentes del deber de garante). Exigencia que supone, en caso de mantenerse el autor cercano a la víctima, que éste hubiese podido evitar la situación de peligro, lo que "demuestra que detrás de la alternativa del abandono se oculta un delito de omisión. Más precisamente, se trata de hacer imposible la propia acción de salvamento" ${ }^{35}$. Cuestión discutida bajo la denominación omissio libera in causa.

Haciendo una comparación con nuestro artículo 352, en primer lugar se puede dilucidar la distinta ubicación del tipo de abandono, ya que el Strafgesetzbuch lo ubica en la sección referida a los delitos contra las personas, cuestión que no sucede en nuestra legislación, aunque hay quienes afirman que la decisión alemana sería la correcta como tendremos ocasión de ver.

En segundo lugar, tratándose de la modalidad básica de comisión del tipo del artículo 221, lo importante respecto del sujeto pasivo es que la persona se encuentre en situación de desamparo o bien que el autor con su acción la deje en tal condición. Con todo, lo determinante para la consumación

\footnotetext{
${ }^{41}$ Struensee, E., cit. (n. 38), p. 84.

${ }^{42}$ Ibíd., p. 86.

${ }^{43}$ Ibíd., p. 87.

${ }^{44}$ Ibíd., p. 87.

${ }^{45}$ Ibíd., p. 88.
} 
es que a la víctima se le coloque en una situación de peligro, cuestión que si bien en nuestra figura de abandono puede deducirse de la exigencia de lesiones graves o muerte del abandonado para que la figura sea punible, no se menciona explícitamente. Resultados que por lo demás (en un sentido vulgar) son considerados por nuestra doctrina como condiciones objetivas de punibilidad, a diferencia de lo que sucede en el caso alemán, ya que se configuran como resultados preterintencionales.

Por último, podemos destacar que la exigencia de que el abandono en situación de desamparo sea efectuado por quien tenga la obligación de asistir a la víctima no se restringe únicamente a casos de vínculo por parentesco o matrimonial como lo hace nuestro Código Penal, limitándose así la punibilidad de nuestra figura, lo que se explicaría tanto por la ubicación de nuestra disposición como por la historia de su establecimiento, ya que para algunos su objeto mediato sería la protección del orden de las familias, como tendremos ocasión de analizar.

\section{Elementos DEL TIPO PENAL}

\section{Bien jurídico.}

El bien jurídico se ha definido tradicionalmente como un bien vital de la comunidad o individuo que en razón de su significado social es amparado y protegido por el ordenamiento jurídico, en este caso particular por el sistema penal. Se ha afirmado también que puede presentarse en las formas más diversas, como objeto psicofísico, ideal-psíquico, como estado real, relaciones de la vida, relaciones jurídicas e incluso como la conducta de un tercero ${ }^{46}$.

Tratándose de la determinación del interés protegido por el artículo 352 CPen. las opiniones doctrinales involucran tanto la vida y seguridad de la persona como el deber de asistencia impuesto por la ley. En efecto, Garrido Montt sostiene que lo protegido, según el espíritu del legislador, "es el desarrollo adecuado de la familia, a la cual la Constitución le reconoce en el artículo 1 inciso $2^{\circ}$ su carácter de 'núcleo fundamental de la sociedad' -la cual- tiene, entre otros, un rol de mutua protección de los que la integran, a los cuales el ordenamiento jurídico les ha impuesto deberes recíprocos de asistencia. La violación de esa obligación cuando significa un riesgo para la vida o salud de la víctima, la reprime con sanción penal - de esta manera- el deber de asistencia del cónyuge o pariente se alza como bien jurídico digno de protección penal" ${ }^{47}$. En este mismo sentido se ha afirmado que se trataría

\footnotetext{
${ }^{46}$ Welzel, Hans, Derecho penal. Parte general (Buenos Aires, Depalma, 1956), p. 6.

${ }^{47}$ Garrido Montt, Mario, Derecho penal. Parte especial (3a edición, Santiago, Editorial Jurídica de Chile, 2007), II, p. 233.
} 
de un delito en que el bien jurídico protegido sería la seguridad de las personas, pero ello unido al cumplimiento de deberes de asistencia que impone la ley entre personas relacionadas por lazos familiares ${ }^{48}$. Así por lo demás lo sostiene la Corte de Apelaciones de Valparaíso en un fallo pronunciado en 1973, que al parecer es el único caso en que se haya dictado sentencia condenatoria por este delito ${ }^{49}$.

En concordancia con ello Etcheberry postula que lo que se sanciona es "primordialmente la violación de deberes de asistencia familiar" 50 . Y agrega que "como entre nosotros este delito contiene numerosas referencias a ciertos deberes de asistencia familiar, nos parece preferible no distorsionar demasiado el sistema del Código y tratarlo en este capítulo" ${ }^{51}$, esto es, el referido a los delitos contra el orden de las familias, contra la moralidad pública y contra la integridad sexual. Con todo, más adelante agrega "que si bien es un delito de lesión contra la vida o integridad corporal y salud de las personas, no está reglamentado entre los delitos contra las personas porque dicha lesión no es aquí directamente querida por el agente, si tal fuera el caso, se trataría derechamente de un delito de homicidio o lesiones" ${ }^{\prime 2}$.

Así por lo demás lo reconoce en cierta medida Labatut Glena ${ }^{53}$, al afirmar que lo protegido sería tanto la salud, vida y seguridad de las personas, según los casos ${ }^{54}$. De esta forma queda demostrada la pluralidad de intereses que la doctrina identifica como protegidos jurídicamente, aunque también hay quienes limitan el bien jurídico protegido exclusivamente a la vida y salud de las personas. Tal es la postura de Politoff, Matus y Ramírez ${ }^{55}$. Idea que por lo demás es concordante con sostener que tanto el abandono de niños como de personas desvalidas han sido ubicadas de manera errónea en el título $7^{\circ}$

${ }^{48}$ Sepúlveda Soto, M. E., cit. (n. 10), p. 29.

${ }^{49}$ Sentencia de la Corte de Apelaciones de Valparaíso, de 28 de noviembre de 1973, en Revista de Derecho, Jurisprudencia y Ciencias Sociales y Gaceta de los Tribunales, 70 (1973), pp. 111-114.

${ }^{50}$ Etcheberry, Alfredo, Derecho penal ( 3 a edición, Santiago, Editorial Jurídica de Chile, 1998), IV, p. 17.

${ }^{51}$ Ibíd., IV, p. 11.

${ }^{52}$ Ibíd., IV, p. 17.

${ }^{53}$ Labatut, Gustavo, Derecho Penal (7 $7^{a}$ edición, Santiago, Editorial Jurídica de Chile, 1983), II, p. 131.

${ }^{54}$ Así por ejemplo MuÑoz Conde, cit. (n. 14), p. 311, respecto de los artículo 226, 229 y 230 del Código Penal español que contiene figuras análogas a nuestro artículo 352. Autor que entiende tal bien jurídico protegido (la seguridad) como la "expectativa jurídicamente fundada que puede tener toda persona de ser ayudada por sus familiares".

${ }^{55}$ Politoff, Sergio - Matus, Jean-Pierre - Ramírez, María Cecilia, Lecciones de derecho penal chileno. Parte especial (2a edición, Santiago, Editorial Jurídica de Chile, 2005), p. 154. 
del libro II, lo que en ningún caso comprometería al intérprete en materias de fondo ${ }^{56}$, como sería en este caso, la determinación del bien jurídico protegido. Puesto que "ello no empece a que su verdadero objeto de protección sea la vida y la salud de las personas que, por su menor edad o desvalimiento se encuentran en un modo u otro bajo el cuidado de terceros" ${ }^{\text {"57. }}$.

Conclusión que también se desprendería al atender que la sanción prevista por el legislador "está condicionada a que la víctima muera o resulte lesionada, lo que revela que ni siquiera en este caso el cumplimiento de deberes familiares es lo que en primera línea se busca proteger, sino concretamente la vida y a salud del abandonado"s8.

\section{Conducta.}

El artículo 352 sanciona al que "abandonare” a su cónyuge, ascendiente o descendiente. Luego, una primera aproximación podemos obtenerla del Diccionario de la Real Academia Española que define el abandono como "dejar, desamparar a alguien o algo".

$\mathrm{Al}$ respecto la doctrina nacional ha entendido que el abandono de personas puede ser físico o material, económico o simplemente moral pero que sólo el primero constituye delito ${ }^{59}$. Abandono que responde al propósito del hechor "de sustraerse a la atención y cuidado y de las personas que, a cualquier título, se encuentra bajo su vigilancia o dependencia" ${ }^{60}$. De esta manera, Garrido Montt (haciendo una remisión a lo dicho respecto del abandono de niños ${ }^{61}$ ) afirma que "hay un abandono típico cuando, además de la acción de abandono, se expone al menor a un peligro concreto, sea de su vida o de su salud. Si esa situación de riesgo específico no se produce, no habría delito" ${ }^{62}$.

Siguiendo con la delimitación de esta figura nuestra doctrina acude también al derecho comparado, citándose entre otros a Soler, quien sostiene "que el abandono puede asumir dos formas: o bien llevar a la persona fuera del ambiente de protección en que se encontraba, dejándolo sin otra, en cuyo caso se procede trasladando al que luego es abandonado, o bien, alejándose el

\footnotetext{
${ }^{56}$ Politoff, S. - Grisolía, F. - Bustos, J., cit. (n. 5), p. 265.

${ }^{57}$ Politoff, S. - Matus, J.-P. - Ramírez, M. C., Lecciones de derecho penal chileno. Parte especial, cit. (n. 55), p. 166.

${ }^{58}$ De la FUente, Felipe, Abandono de niños y personas desvalidas (inédito.

${ }^{59}$ Labatut, Gustavo, Derecho penal, cit. (n. 53), II, p. 131.

${ }^{60}$ Ibíd., p. 131.

${ }^{61}$ Garrido Montt, M., Derecho penal. Parte especial, cit. (n. 47), II, p. 238, ya que "todo lo comentado sobre lo que se entiende por abandono en párrafos precedentes -abandono de niños- se da por reproducido en esta oportunidad", tratando ahora el tipo del artículo 352.

${ }^{62}$ Ibíd., II, p. 238
} 
sujeto activo mismo del ambiente de protección y dejando en el mismo lugar al abandonado. En la primera forma, el hecho no consiste en privar al sujeto pasivo de la propia protección, sino en dejarlo sin ninguna. En consecuencia, no existe este delito cuando la víctima es abandonada en un lugar donde es seguro que prontamente y sin peligro para la salud, no ya para la vida, será atendida, sea por persona determinada o indeterminada, sin que corra realmente ningún riesgo apreciable de daño en la persona" ${ }^{3}$. De este modo concluye que más que el eventual alejamiento o no del autor, lo que configura el tipo del artículo 106 CPenArg. ${ }^{64}$ es la situación de peligro creada por el autor. Situación de peligro que ha de medirse según este autor acudiendo al criterio de lo que normalmente puede ocurrir. Y por tanto "para excluir el delito, es preciso que el sujeto que realiza el abandono pueda tener una esperanza justificada de que el auxilio ocurrirá, pero no basta la simple posibilidad de que ocurra" ${ }^{\text {" }}$.

En cuanto a la postura de nuestra doctrina acerca de si estamos frente a un delito activo u omisivo, Garrido Montt afirma que se trata de un delito de omisión propia ${ }^{66}$, pero lo hace considerando un criterio de clasificación distinto, esto es, que estamos frente a una omisión descrita en el respectivo tipo penal ${ }^{67}$, a diferencia de lo que para estos efectos consideramos el criterio a aplicar, consistente en delitos que se consuman por un mero no hacer la actividad ordenada. Precisamente en este último sentido lo sostiene Cornejo Manríquez ${ }^{68}$.

Empleando la terminología de Silva Sánchez, se trataría en este caso de una omisión pura de garante, ya que tendría su fundamento en la existencia de una base funcional específica "lo que determina que sólo puedan ser realizadas por un determinado círculo de sujetos caracterizados por la ostentación de una posición de responsabilidad especial. Por esta misma razón -sostiene el autor- se trataría de omisiones de mayor gravedad, en idénticas circunstancias que las generales" ${ }^{69}$. Ello porque el artículo 352 exige que el sujeto

${ }^{63}$ Soler, Sebastián, Derecho penal argentino (4a edición, Buenos Aires, Huknos Airks, 1992), pp. 187-188.

${ }^{64}$ Ya analizado y que prescribe: "El que pusiere en peligro la vida o la salud de otro, sea colocándolo en situación de desamparo, sea abandonando a su suerte a una persona incapaz de valerse y a la que deba mantener o cuidar o a la que el mismo autor haya incapacitado, será reprimido con prisión de 2 a 6 años".

${ }^{65}$ SOLER, S., cit. (n. 63), p. 188.

${ }^{66}$ Garrido Montt, M., Derecho penal. Parte especial, cit. (n. 47), II, p. 238.

${ }^{67}$ Garrido Montt, Mario, Derecho penal. Parte general (3a edición, Santiago, Editorial Jurídica de Chile, 2003), II, p. 238.

${ }^{68}$ Cornejo, Aníbal, Derecho penal (Santiago, Metropolitana, 2003), p. 6.

${ }^{69}$ SIlva SÁnChEZ, Jesús María, El delito de omisión: concepto y sistema (Montevideo, B de F, 2003), p. 344. 
activo sea un sujeto cualificado que tenga una relación de parentesco o de matrimonio con la víctima.

Entendiendo entonces, por parte de la doctrina que se pronuncia a este respecto, que se trataría de un delito de omisión, surge la cuestión sobre si es un delito de omisión propia o comisión por omisión. Como partidario de la primera solución, de una manera explícita pero sin dar razones de tal postura, Cornejo Manríquez afirma que se trata de un delito de omisión propia, donde "la conducta del sujeto activo (el abandono) debe exponer a la víctima al peligro de dañar su salud o morir (exigencia especial requerida para que pueda imponerse la pena)" 70 . En cambio, a favor de entender que se trataría un delito de comisión por omisión, encontramos a Labatut Glena, quien, al explicar la distinción entre delitos omisivos propios e impropios, señala que forma parte de esta última categoría el abandono de personas desvalidas del artículo 352 CPen. ${ }^{71}$.

Sin embargo a este respecto seguimos la postura de Struensee, quien señala que "abandonar, o más precisamente, el resultado de abandonar es el hacer imposible la propia ayuda"72. Por ello afirmamos que esta conducta típica implica tanto una acción (constitución de la situación de desamparo, que se puede realizar mediante el traslado o alejándose el sujeto activo del ambiente de protección y dejando en el mismo lugar al abandonado) como una omisión (no proporcionar la ayuda necesaria al sujeto pasivo para sobrellevar los peligros que crea la situación de desamparo). Esto último, siguiendo nuevamente a Struensee para quien: "cuando el garante abandona a su víctima, la situación de ésta sólo empeora, ciertamente, si uno no sólo suprime mentalmente la separación espacial (= comprobación de la causalidad del hacer activo según la teoría de la equivalencia), sino que tendrá que agregar mentalmente también que el autor, en caso contrario, habría ayudado a la víctima. Esto presupone que el garante, en caso de mantenerse cerca, habría sido capaz de aventar el peligro amenazante. Con ello se muestra que detrás de la alternativa del abandono se oculta un delito de omisión"73.

Y si bien, Garrido Montt sostiene que "sin perjuicio que la conducta que lleve a ese incumplimiento pueda consistir en una acción positiva (irse de la casa donde está el menor), lo relevante está en que esa acción importa la voluntad de abstenerse de asistir al menor y así dejarlo librado a su suerte"74, coincidimos con De la Fuente, quien critica el argumento anterior por cuanto

${ }^{70}$ Cornejo, A., cit. (n. 68), p. 6.

${ }^{71}$ Labatut Glena, Gustavo, Derecho penal (9a edición, Santiago, Editorial Jurídica de Chile, 1990), I, p. 164.

${ }^{72}$ STRUensee, E., cit. (n. 38), p. 84.

${ }^{73}$ Ibíd., pp. 87-88.

${ }^{74}$ Garrido Montt, M., Derecho penal. Parte especial, cit. (n. 47), II, p. 234. 
“implica suponer - a nuestro juicio erróneamente -que la naturaleza del acto puede determinarse a partir de las exigencias subjetivas del tipo"75.

Se trataría entonces de un delito donde las posibilidades de comisión son por un lado el trasladar al sujeto pasivo a un lugar donde no pueda sortear por si solo los peligros a su vida o salud, o bien alejándose el sujeto activo de la víctima, creando en ambos casos una situación de desamparo o peligro para la víctima. Formas de comisión, que a nuestro entender son principalmente activas, y que con posterioridad dan lugar a una forma omisiva consistente en no prestar auxilio en sentido amplio, evitando así la muerte o lesiones de la víctima. Omisión consciente y voluntaria “que constituirá algo «interpretable» al que cabe atribuir un contenido de sentido, también un contenido de sentido típico. Superados los obstáculos derivados del causalismo naturalista (por ese no hacer algo), debe, pues, atribuírsele carácter de acción" ${ }^{76}$. Creemos entonces que se trata de un delito activo que siempre trae aparejado una omisión, en el sentido ya explicado por Struensee. Si bien una opinión así puede cuestionarse, entendemos también que "el sentido que se asigne a un hecho del hombre depende, pues, del punto de visa adoptado. En el caso del Derecho Penal, es en los diferentes tipos donde se procede a la interpretación que asigna contenidos de sentido a tales procesos. El papel del concepto de conducta consiste, en fin, en decidir qué procesos son interpretables, esto es, accesibles a la interpretación típica"77.

\section{Sujeto activo.}

El artículo 352 CPen. prescribe "el que abandonare a su cónyuge o a un ascendiente o descendiente, legitimo o ilegítimo [...]". Exige, por tanto, la concurrencia de un sujeto calificado, y se convierte además en un delito especial propio al no existir figura base común. A ello se agrega que el sujeto activo debe haber estado legalmente o de hecho al cuidado de la víctima, ya que de no ser así, no podría apreciarse el abandono ${ }^{78}$. Esta restricción, según lo afirmado por Politoff, Matus y Ramírez correspondería al ideario liberal de los redactores del Código ${ }^{79}$. Restricción que por lo demás ha sido criticada por nuestra doctrina. Así Politoff, Grisolía y Bustos afirman que ello revelaría la mentalidad individualista del legislador "que se abstiene de castigar todo otro caso de abandono de personas destituidas física o psíquicamente

${ }^{75}$ De la fuente, F., cit. (n. 58).

${ }^{76}$ Silva Sánchez, J. M., El delito de omisión, cit. (n. 69), p. 132.

${ }^{77}$ Ibíd., p. 131.

${ }^{78}$ Garrido Montt, M., Derecho penal. Parte especial, cit. (n. 47), II, p. 238.

${ }^{79}$ Politoff, S. - Matus, J.-P. - Ramírez, M. C., Lecciones de derecho penal chileno. Parte especial, cit. (n. 55), p. 171. 
y en riesgo grave para su vida y salud"80. En el mismo sentido, De la Fuente sostiene "que la estrechez de la órbita de autores deja fuera del tipo a sujetos tan importantes como el conviviente y los encargados de la custodia de un menor o discapacitado". Y que "quedan también fuera del tipo los que de hecho se encuentren al cuidado de un sujeto en tal estado de dependencia" 81. Ello demostraría, como señala Labatut Glena, que nuestro legislador "ha restringido considerablemente el campo de este delito, pues es mucho más exigente que cuando se trata de abandono de niños" $"$.

\section{Sujeto pasivo.}

Respecto del sujeto pasivo, además del ya expresado vínculo que debe existir con el autor del delito, la ley exige que se trate de una persona enferma o imposibilitada. Conceptos que, como señala Etcheberry, si bien son bastante amplios, "deben ser precisados a la luz del epígrafe del párrafo, que se refiere al abandono de una persona 'desvalida" "83. De forma que no cualquier enfermedad o imposibilidad es suficiente, sino que debe tratarse de una que "imposibilite a la persona para valerse por sí misma, o bien, para defenderse de los peligros que eventualmente la amenacen o de procurarse la asistencia que necesita para el mantenimiento de su vida y salud" ${ }^{44}$. De esta manera, como afirman Politoff, Grisolía y Bustos, la eventual enfermedad o imposibilidad de la víctima debe "corresponder a las características del peligro concreto" $\$ 5$. Enfermedad que por lo demás puede ser física o mental. Y por otro lado, la imposibilidad a su vez puede derivar de diversas causas, como la privación de sentido, inmovilidad por ataduras, etc. Así como puede tratarse de características permanentes o bien transitorias "siempre que su duración sea suficiente como para hacer previsible la posibilidad de muerte o lesiones graves" $"$. Al respecto hay que tener presente que "se puede estar imposibilitado sin estar enfermo, como sucede con algunos minusválidos, o con personas de avanzada edad" $"$. A modo ejemplar del tipo de enfermedad o imposibilidad típica, la Corte de Apelaciones de Valparaíso, con fecha 28

${ }^{80}$ Politoff, S. - Grisolía, F. - Bustos, J., cit. (n. 5), p. 273.

${ }^{81}$ De la fuente, F., cit. (n. 58).

${ }^{82}$ Labatut, G., Derecho penal, cit. (n. 53), II, p. 132.

${ }^{83}$ Etcheberry, A., Derecho penal, cit. (n. 50), IV, p. 17.

${ }^{84}$ Ibíd., IV, p. 17.

${ }^{85}$ Politof, S. - Grisolía, F. - Bustos, J., cit. (n. 5), p. 273.

${ }^{86}$ Etcheberry, A., Derecho penal, cit. (n. 50), IV, p. 17.

${ }^{87}$ Politoff, S. - Matus, J.-P. - Ramírez, M. C., Lecciones de derecho penal chileno. Parte especial, cit. (n. 55), pp. 238-239. 
de noviembre de 1973 sancionó por este delito el abandono de una persona que padecía oligofrenia ${ }^{88}$.

\section{Aspectos circunstanciales y medios de ejecución.}

En primer lugar respecto de los aspectos circunstanciales, no exige el tipo del artículo 352 requisito alguno, siendo indiferente el lugar en que se comete el delito. Así Etcheberry, sostiene que "la ley no distingue aquí entre lugares solitarios y no solitarios ni atiende a la edad de la persona abandonada" ${ }^{\prime \prime}$, como sí lo hace nuestro legislador respecto de las figuras de abandono de niños de los artículo 346 a 351 CPen.

En segundo lugar, tratándose de los medios de ejecución del delito, tampoco señala nuestro legislador restricción alguna. No obstante, a modo ilustrativo, podemos señalar lo que ha ocurrido tratándose de figuras análogas en derecho comparado. Así por ejemplo en España se han considerado como medios de ejecución del delito, el que el sujeto activo se ausente del hogar en el que reside el sujeto pasivo, dejando a éste sin comida ni medios de subsistencia, o bien dejando al enfermo o imposibilitado en la calle o en el hospital. Incluso, se han sancionado casos de abandono temporal, caracterizados por un dolo específico, consistente en que la voluntad de abandonar no es definitiva ${ }^{90}$. Del mismo modo, pero ya desde una perspectiva estrictamente teórica, se han dado para el caso alemán ejemplos como el caso de una campesina solitaria de granja de montaña que no dispone de medios de comunicación y sale de su casa para ordeñar sus vacas, no pudiendo ayudar ni aliviar los padecimientos de su marido que yacía en cama y que en ese intertanto fallece de un infarto ${ }^{91}$.

\section{Muerte y lesiones: ¿elementos del tipo o condiciones objetivas de puni- bilidad?}

El problema sobre la naturaleza jurídica de la muerte o lesiones que exige el artículo 352 aparece unido en nuestra doctrina a la determinación de si estamos frente a un delito de lesión o de peligro, sea este concreto o abstracto. De esta manera las posturas son las siguientes:

Algunos entienden que estamos frente a un delito de lesión contra la vida o salud de las personas y que en consecuencia la muerte y lesiones son resultados del delito de abandono. Así Etcheberry y Labatut. El primero lo

${ }^{88}$ Sentencia de la Corte de Apelaciones de Valparaíso, de 28 de noviembre de 1973, en Revista de Derecho, Jurisprudencia y Ciencias Sociales y Gaceta de los Tribunales, 70 (1973), pp. 111-114.

${ }^{89}$ Etcheberry, A., Derecho penal, cit. (n. 50), IV, p. 17.

${ }^{90}$ Cfr. Gómez Tomillo, M., cit. (n. 13), pp. 175-198.

${ }^{91}$ Struensee, E., cit. (n. 38), p. 87. 
señala expresamente al afirmar que este es un "delito de lesión contra la vida o integridad corporal y salud de las personas (pero que) no está reglamentado entre los delitos contra las personas, porque dicha lesión no es aquí directamente querida por el agente, si tal fuera el caso, se trataría derechamente de un delito de homicidio o de lesiones. Respecto de la muerte o lesiones graves, el abandonante se encuentra en situación de culpa inconsciente, consciente o dolo eventual" 92 . Por otro lado, Labatut si bien no lo señala explícitamente, podemos extraer su opinión haciendo una relación de sus opiniones vertidas en las obras Derecho penal: tomo I (parte general) y tomo II (parte especial). Así en la segunda afirma "que el hecho es delictuoso sólo en caso de que la víctima sufra lesiones graves o muera a consecuencia del abandono" ${ }^{\text {, } 3}$, sin dar mayores luces sobre su naturaleza jurídica. Sin embargo, en el tomo I ${ }^{94}$, al tratar la particular clasificación de los delitos omisivos, señala que este delito es un caso de comisión por omisión. Lo que daría a entender que en este caso el autor, en posición de garante de la vida de la víctima, omite la conducta debida que habría evitado la muerte o lesiones, constituyéndose así como un delito de resultado.

Postura que si bien cuenta con otros adherentes ${ }^{95}$ no es la mayoritaria en nuestra doctrina, ya que se ha impuesto la idea de que estaríamos frente a una condición objetiva de punibilidad y en consecuencia ante un delito de peligro. Así Garrido Montt, quien afirma que "esta consecuencia de la conducta no es el resultado del delito, porque el tipo penal es de peligro y no lo requiere para consumarse, pero sí lo exige para que se pueda punir, el delito se perfecciona por la simple inejecución de la actividad esperada por el agente" 96 . En el mismo sentido Cornejo Manríquez, quien si bien no lo dice explícitamente, señala que estamos frente a un delito de peligro concreto porque la conducta de abandono debe traducirse en un daño a la salud de la víctima (lesiones graves) o en su muerte. De manera que "la conducta del sujeto activo debe exponer a la víctima al peligro de dañar su salud o morir (exigencia especial requerida para que pueda imponerse la pena)"97. Misma opinión sostienen Politoff, Grisolía y Bustos para quienes "la verdad es que el legislador suele circunscribir, y éste es uno de los casos, la clase de riesgo incriminado mediante condición objetiva de punibilidad, pero ello en nada altera, según se ha dicho antes, la naturaleza misma del delito como delito

\footnotetext{
${ }_{92}$ Etcheberry, A., Derecho penal, cit. (n. 50), IV, p. 17.

${ }^{93}$ Labatut, G., Derecho penal, cit. (n. 53), II, p. 123.

${ }^{94}$ Ibíd., I, p. 164.

${ }^{95}$ Sepúlveda, M. E., cit. (n. 10), p. 29.

${ }^{96}$ Garrido Montt, M., Derecho penal. Parte especial, cit. (n. 47), p. 239.

${ }^{97}$ Cornejo Manrí uez, A., cit. (n. 68), p. 6.
} 
de peligro"98. Postura sostenida también por Politoff, Matus y Ramírez ${ }^{99}$ y De la Fuente. Sin embargo este último cuestiona tal decisión legislativa al señalar que "llama la atención el criterio del legislador en esta materia, porque siendo el sujeto activo un individuo sobre el que recae un específico deber de cuidado respecto de su cónyuge o pariente, y uno al que, por lo mismo, siempre le podría ser imputada la no evitación de la muerte de éste conforme a las reglas generales, cabría esperar que en este caso se le sancionase por el sólo hecho de poner en peligro la vida de la víctima, al abandonarla a su suerte"100.

Para una toma de postura sobre esta problemática primero es necesario tener en consideración la fundamentación de las condiciones objetivas de punibilidad y su distinción frente a un elemento del injusto y de la culpabilidad, de manera de poder identificar la naturaleza jurídica de la exigencia del artículo 352.

Para ello partimos de un concepto de condiciones objetivas de punibilidad que las define como "ciertos excepcionales requisitos de hecho, extrínsecos al delito e independientes de sus elementos constitutivos, que la ley exige en determinados casos para la imposición de la pena. Son eventos futuros e inciertos, sin cuya concurrencia el delito existe ontológicamente, pero no pueden castigarse; suponen un hecho punible completo en sus elementos y son independientes de la voluntad del sujeto"101. Son por tanto, restricciones de punibilidad cuyo fundamento está en razones de política criminal y que por referirse a una circunstancia cuya realización es independiente de la voluntad del sujeto activo no puede integrar la descripción típica. Por ello se afirma que "esas condiciones no constituyen elementos que se vinculen con el merecimiento de pena, sino con la necesidad de la misma"102.

$\mathrm{Al}$ respecto, entendemos como merecedora de pena "aquella conducta que merece la desaprobación ético-social por su capacidad para poner en peligro o dañar gravemente las relaciones sociales dentro de la comunidad jurídica" ${ }^{103}$. Para cuya determinación no sólo ha de considerarse el desvalor de acción y de resultado, sino también la naturaleza del bien jurídico afectado ${ }^{104}$. En cambio, hablamos de necesidad de pena respecto del juicio de determinación

${ }^{98}$ Politoff, S. - Grisolía, F. - Bustos, J., cit. (n. 5), p. 273.

${ }^{99}$ Politoff, S. - Matus, J.-P. - Ramírez, M. C., Lecciones de derecho penal chileno. Parte especial, cit. (n. 55), p. 170.

${ }^{100}$ De la fuente, F., cit. (n. 58).

${ }^{101}$ Labatut, G., Derecho Penal, cit. (n. 71), I, p. 89.

${ }^{102}$ Garrido Montt, M., Derecho penal. Parte general, cit. (n. 67), II, p. 325.

${ }^{103}$ Mapelli Caffarena, Borja, Estudio jurídico-dogmático sobre las llamadas condiciones objetivas de punibilidad (Madrid, Centro de Publicaciones del Ministerio de Justicia, 1990), p. 31.

${ }^{104}$ Ibíd., p. 31. 
de que la "pena es el medio irrenunciable para proteger la sociedad frente a lesiones o amenazas a bienes jurídicos"105. Agrega Mapelli Caffarena que se "se trata de separar el merecimiento de la pena de las necesidades político criminales. [Ya que] mientras que aquél se determina esencialmente a partir de la valoración del daño social de una conducta, la necesidad de pena toma en consideración sobre todo los fines de la pena estatal" ${ }^{106}$. Necesidad de pena que en general coincide con el juicio de merecimiento, pero en supuestos excepcionales "es preciso que concurra además un especial menoscabo de los valores de orden amparados por el correspondiente precepto penal para que se reconozca la necesidad político-criminal de la pena" ${ }^{107}$.

Se agrega que es posible también que el autor desee la concurrencia de tal circunstancia, pero "aun en tales hipótesis su voluntad no habrá abarcado esa posibilidad, porque nadie puede querer, en el sentido de incorporar a su voluntad de concreción, aquello que sólo está sometido a las leyes de la naturaleza o que depende de la voluntad libre de un tercero" 108 .

Si bien hay autores como Fontán Balestra ${ }^{109}$ que niegan la autonomía de estas condiciones (al entender que son también exigencias del tipo, ya estén contenidas como acción o como resultado, y por tanto, como elementos objetivos del tipo, de igual manera como se contemplan los demás elementos objetivos del tipo), la mayoría de la doctrina entiende que éstas integran la punibilidad del delito. Lo que no soluciona los problemas que genera esta figura, ello porque los autores nacionales no están contestes en la identificación de las mismas. Así se ha afirmado por algunos ${ }^{110}$ que no existirían perfectas condiciones objetivas de punibilidad en nuestro país. En cambio otros han afirmado, reconociéndolas en nuestro ordenamiento, que se ha exagerado el número de ellas. Tal es la postura de Garrido Montt ${ }^{111}$ quien añade que las únicas respecto a las cuales no hay dudas serían la muerte del suicida en el delito de auxilio al suicidio y el daño o entorpecimiento del servicio público en el caso de malversación del artículo 235. A las que Etcheberry agrega el protesto en el delito de giro doloso o fraudulento de cheques ${ }^{112}$.

De esta manera surge la problemática de aparentes condiciones de puni-

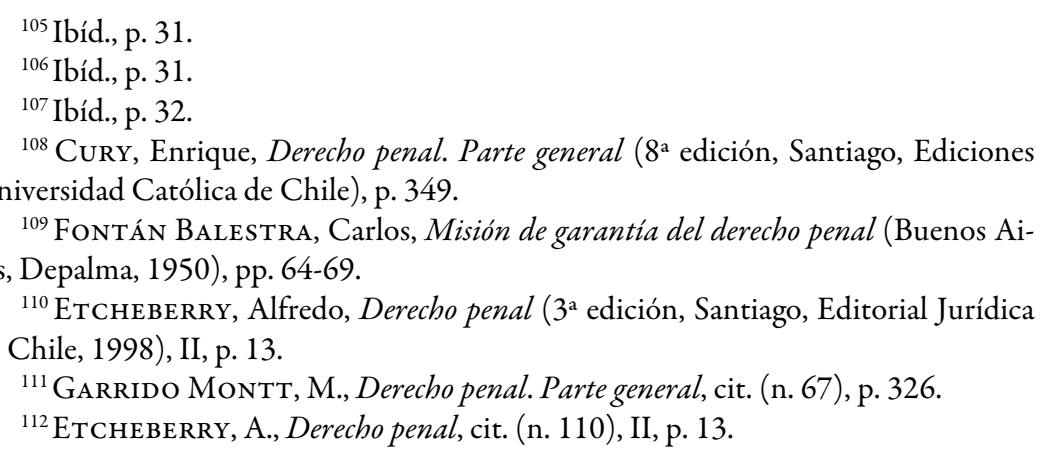


bilidad que en realidad sería elementos del tipo. En este sentido Roxin estima que estaríamos en tal caso tratándose del delito de homicidio en riña ya que "la participación en una pelea insignificante, que no haga temer consecuencias lamentables, no merece una pena de prisión de hasta tres años, sino que lo que quiere el legislador, cuando vincula la punibilidad a la causación de una muerte o de una lesión grave, es castigar de modo específico la participación en agresiones o riñas especialmente peligrosas; y a ese respecto parte de la base de que esa peligrosidad se desprende típicamente de las consecuencias graves. Pero si esto es así, entonces el resultado grave pertenece al injusto típico y la culpabilidad del autor ha de extenderse a los factores que son constitutivos de la peligrosidad; es decir: el sujeto al menos ha de poder prever que la riña podría tener una de las consecuencias mencionadas en el $\$ 227^{\prime \prime 113}$.

Por todo lo dicho, entendemos que en el caso del artículo 352 lo que se exige no calza con la definición estricta de condición objetiva de punibilidad. Ello porque creemos que la muerte y lesiones son parte del injusto y la culpabilidad y no meras consecuencias ajenas al mismo. De esta manera, al igual que lo considerado por Roxin respecto del delito de homicidio en riña, creemos que de la peligrosidad creada por el autor abandonando a una persona enferma o desvalida se produce el resultado muerte o lesiones, de modo que éstas pertenecen al injusto y el sujeto activo debe al menos representárselas como posibles, superando así el juicio de merecimiento de pena. Por lo demás, esta sería la forma de justificar la elevada pena que trae aparejada el delito de abandono (presidio mayor en su grado mínimo), sanción similar a la del homicidio simple. De esta forma podemos sostener que es la conducta de abandonar junto con la causación de lesiones o muerte de la víctima como resultado típico, la merecedora de tal pena.

Creemos además que de lo contrario se llegaría a consecuencias indeseadas, ya que debiésemos sancionar casos en que el sujeto activo por ejemplo deja a la víctima desamparada, y luego ésta fallece de manera accidental (siempre que el sujeto activo hubiese podido evitar el resultado, ciertamente), puesto que, si bien el artículo 352 exige que la muerte y lesiones sean a consecuencia del abandono, no es posible aplicar criterios de imputación objetiva, ello por cuanto estas condiciones objetivas no forman parte del tipo y son por tanto ajenas al injusto y a la culpabilidad. De manera que bastaría simplemente la asunción de criterios meramente naturalísticos de causación, lo que a nuestro entender no se aviene con el principio de culpabilidad.

Si bien entendemos que en cierta manera ello se ha intentado solucionar al desvincular la muerte y las lesiones del abandono en el ámbito de la atribución subjetiva de dicho resultado a quien tiene el dominio de la acción, en

${ }^{113}$ Roxin, Claus, Derecho penal. Parte general (2a edición, Civitas, 1997), I, p. 974. 
el ámbito del dolo y no, por el contrario, en el ámbito objetivo-normativo, donde dicho resultado debe ser imputable a la acción típica ${ }^{114}$, creemos de todas formas que la crítica subsiste, ya que los criterios para hacer tal imputación a la acción típica necesariamente incluyen una consideración a la conducta del autor.

Por lo demás, la crítica acostumbrada consiste en afirmar que las condiciones objetivas de punibilidad contravienen el principio de culpabilidad y de responsabilidad penal. Ello porque "la punibilidad presupone culpabilidad, es decir, reprochabilidad y ésta no puede imputarse cuando la circunstancia de que se trata no ha sido dolosa ni culposamente abarcada y, en segundo lugar, la culpabilidad debe ser probada y no presumida. Dos circunstancias que convierten los elementos condicionantes en una categoría ajena al injusto y a la culpabilidad"115. Objeción que ha llevado a algunos autores como Bemmann y Zaffaroni ${ }^{116}$ a coincidir en que éstas infringen el principio de culpabilidad y en consecuencia deben ser tratadas como elementos del injusto o bien, como condiciones de procedibilidad (circunstancias condicionantes constituidas de tal forma "que no se ajusta a la idea de pena, sino que está relacionada con el si y el cómo de la actividad procesal"117. Constituyéndose como "presupuestos formales que sólo incidirían en la realización de la pretensión punitiva"118. Y que al no corresponder al derecho penal y siendo procesales "no excluyen la punibilidad, sino la perseguibilidad"119.) Teniendo además presente que "las condiciones no siempre son instrumentos que restringen la pena, sino que en ocasiones la fundamentan o agravan" 120 .

Por tanto, entendiendo que la muerte o lesiones no son condiciones de punibilidad ni de procedibilidad, creemos que deben ser tratadas como elementos del tipo. Determinación que no está exenta de críticas, ya que lo conveniente sería tipificar el abandono de personas desvalidas como delito

${ }^{114}$ Como lo hace Soto Piñeiro, Miguel, La apropiación indebida (Santiago, Editorial Jurídica ConoSur, 1994), p. 70, respecto del perjuicio como condición objetiva de punibilidad en el delito de apropiación indebida.

${ }^{115}$ Mapelli Caffarena, B., cit. (n. 103), p. 40.

${ }^{116}$ Ibíd., p. 40.

${ }^{117}$ Beling, Ernst von, Derecho procesal penal (traducción de Miguel Fenech, Madrid, Labor, 1943,), p. 6, cit. por Mendes De CARvalho, Érika, Las condiciones de procedibilidad y su ubicación sistemática. Una critica al sistema integral del derecho penal, en Revista Electrónica de Ciencia Penal y Criminología, 24 (2005) 7, p. 10 [visible en internet: http://criminet.ugr.es/recpc/07/recpc07-10.pdf]

${ }^{118}$ Mendes de Carvalho, E., cit. (n. 117), p. 10.

${ }^{119}$ Beling, Ernst von, Esquema de Derecho Penal. La doctrina del delito-tipo. Análisis de Carlos M. de Elía (Buenos Aires, Librería el Foro, 2002), p. 127.

${ }^{120}$ Mapelli Caffarena, B., cit. (n. 103), p. 40. 
de peligro concreto, y para el caso que se produzcan los resultados de muerte o lesiones agravar la pena impuesta, al igual que en el caso argentino.

\section{Aspecto subjetivo.}

Entendiendo el delito de abandono de personas desvalidas como un delito de resultado, podemos imaginar diversas hipótesis en lo que respecta al aspecto subjetivo del mismo. En primer lugar, que tanto el abandono como el resultado muerte o lesiones se cometan con dolo directo, es decir, que el abandono del cónyuge, ascendiente o descendiente enfermo o imposibilitado se estime como el modo específico para lograr tal resultado. En segundo lugar, que respecto del abandono y resultado, estos sean cometidos con dolo eventual del hechor, esto es, se prevea tanto la constitución de una situación de peligro para la vida y salud del sujeto pasivo (estado de desamparo) y la concretización de ese peligro (resultado) como algo probable y aceptado por el sujeto activo. Y por último, que el abandono de la víctima se cometa con dolo directo por parte el hechor, mientras que el resultado, tanto la muerte como las lesiones, sean causados culposamente. De forma que la voluntad del hechor estaría dirigida a la constitución de una situación de desamparo y de peligro para la vida y salud de la víctima, pero el resultado adicional que se causa va más allá del objetivo del autor, existiendo, sin embargo culpa respecto del mismo.

Sin embargo, en esta última hipótesis debemos rechazar que el resultado pueda cometerse con culpa, entendiendo que respecto del delito del artículo 352 no se prevé expresamente la posibilidad de su comisión culposa (atendiendo el criterio numerus clausus) ni tampoco existe una cláusula general que lo permita, ello por cuanto la remisión que hace el artículo 490 es exclusivamente a los delitos contra las personas. Ello unido además a la penalidad que traería aparejada, porque de ser castigado de conformidad a la figura de abandono de personas desvalidas, el autor arriesgaría una pena de presidio mayor en su grado mínimo, siendo que, de negarse tal posibilidad se podría castigar tal conducta por el delito de homicidio simple culposo (entendiendo que la conducta matar abarca la de abandonar, lo que se examinará en el siguiente apartado, y teniendo presente además que para la aplicación de la figura de parricidio no se contempla su comisión culposa), en que el marco penal es de reclusión o relegación menores en sus grados mínimo a medio.

En suma, desde el punto de vista subjetivo, este delito exige dolo directo o eventual tanto respecto de la conducta (el abandono que crea una situación de peligro para la vida o salud de la víctima) como respecto de los resultados típicos (muerte o lesiones). 


\section{RELACIONES CONCURSALES}

\section{Homicidio.}

En particular, la eventual relación concursal debe analizarse respecto de la figura de parricidio contemplada en el artículo 390 CPen., teniendo en consideración la exigencia del artículo 352 respecto del especial vínculo que ha de existir entre el sujeto activo y pasivo.

Relación que consistiría en un concurso aparente de leyes penales, por las razones que a continuación se expondrán. Y para resolver tal concurso, haremos una distinción tanto respecto a las exigencias típicas de la conducta misma como respecto al sujeto activo y pasivo, entendiendo que el bien jurídico protegido y el resultado exigido son los mismos en ambos delitos.

Primeramente en lo referente a la conducta, por un lado tenemos la exigencia del artículo 352 consistente en que a consecuencia del abandono es que se produce la muerte de la persona. Resultado que como elemento de tipo debe ser abarcado por el dolo del agente, que como ya señalamos puede tratarse tanto de dolo directo como eventual.

Más complejo aún es el caso en que la muerte sea precisamente el resultado buscado por el sujeto activo, el que se representa a su vez, la forma de comisión mediante el abandono de la víctima, es decir, que exista dolo directo tanto respecto de la conducta como del resultado. Para este caso entendemos que precisamente el abandono es la especial forma de dar muerte a una persona con la cual existe una relación de parentesco o de matrimonio. Conducta que podemos comprender en el verbo rector matar, que contempla la figura de parricidio porque "la ley no se preocupó de describir una conducta concreta circustanciándola, se refiere en general a la acción de matar, lo que obliga al enfrentar un comportamiento dado, mirarlo no sólo en su significación naturalista; debe recurrirse al fin que con el actuar se perseguía, pues las acciones en sí son neutras en general, indiferentes, si se consideran al margen del aspecto direccional que les es inherente" 121 .

Ello respecto de la conducta activa de matar a otro, requisitos que en los hechos (el abandono con resultado de muerte), podrían configurar tanto la hipótesis del artículo 352 como del artículo 390. Con todo, la conducta homicida en el caso del parricidio sigue siendo más amplia, por cuanto "esta conducta positiva puede consistir, y quizás sea lo frecuente, en el movimiento de las extremidades, que son los órganos empleados al efecto por el ser humano; pero la acción puede concretarse también con una palabra o con un gesto, que importa el solo movimiento de determinados músculos. No

${ }^{121}$ GARrido Montt, Mario, El homicidio y sus figuras penales (Santiago, Encina, 1976), p. 22. 
se interesó el legislador en diferenciar los medios por los cuales se provoca la muerte, considera en igualdad de condiciones el empleo de medios físicos, mecánicos o vivos" 122 .

Por otro lado, la doctrina suele distinguir entre medios para cometer el delito de homicidio directos e indirectos, siendo los "directos aquellos que obran de manera inmediata sobre la víctima para provocarle la muerte”, y los indirectos, "aquellos que pueden no ser en sí letales, pero que al operar con otras circunstancias o modalidades existentes o puestas en acción por el comportamiento del agente traen como resultado la muerte. $\mathrm{Al}$ respecto "Maggiore cita entre éstos el azúcar a un loco o a un animal contra la víctima, exponer a un recién nacido al viento frío, hacer trabajar a un hombre en un lugar infectado, obligar al suicidio" 123 .

Por tanto, y a partir de esta distinción, podemos advertir una nueva particularidad de la conducta del artículo 352 , el consistir en un medio indirecto, por cuanto si bien el sujeto activo abandona a la víctima, la concurrencia de esta circunstancia con el peligro creado por el autor, más las condiciones especiales del sujeto pasivo (el encontrarse enfermo o imposibilitado) son todas ellas causas concurrentes en la muerte del abandonado.

Luego, entendemos que en lo que respecta a la conducta de abandonar, puede entenderse incluida en el verbo matar. No obstante, la conducta del delito de parricidio sigue siendo más amplia, de acuerdo a lo ya señalado, lo que permitiría abarcar en este delito conductas que no podemos considerar como abandono, por ejemplo causar la muerte de otra persona por medios inmateriales o morales, así como conductas que atentan directamente contra la integridad de la persona.

En segundo lugar, respecto del sujeto activo, podemos decir que no hay plena coincidencia entre estos tipos penales. El delito de parricidio puede ser cometido por un ascendiente, descendiente, cónyuge, conviviente, e incluso por aquella persona que hubiere sido cónyuge o conviviente de la víctima. Situación que no se repite en el tipo del artículo 352, ya que únicamente pueden cometer este delito el ascendiente, descendiente o cónyuge del abandonado.

En tercer lugar, respecto del sujeto pasivo, el artículo 352 contiene una especial exigencia que no se contempla en el delito de parricidio, se trata de la circunstancia de que el abandonado se encuentre enfermo o imposibilitado. Elemento que junto a las otras particularidades ya analizadas nos lleva a sostener que este concurso aparente de leyes penales se soluciona mediante el principio de especialidad. Principio que consiste en que "cuando de la consideración de dos o más normas penales, lleguemos a la conclusión de

\footnotetext{
${ }^{122}$ Ibíd., p. 23.

${ }^{123}$ Ibíd., p. 26.
} 
que ellas contemplan hechos similares con diversos grados de precisión, la que contemple los hechos con mayor minuciosidad o comprensión debe ser aplicada con exclusión de las otras" ${ }^{124}$.

Abona a esta conclusión el que tratándose del aspecto subjetivo del delito de parricidio, una parte minoritaria de la doctrina entiende que sólo puede cometerse con dolo directo, mientras que la postura doctrinal y jurisprudencial mayoritaria admiten hipótesis de parricidio con dolo eventual, siempre que la eventualidad se refiera a la forma de concreción de la muerte y no incida en el conocimiento de la especial relación que existe entre el sujeto activo y pasivo.

De forma que, y quedándonos con la postura mayoritaria ya analizada en lo referente al parricidio, en comparación con el delito de abandono, se da una situación similar, ya que si bien el artículo 352 no exige de manera expresa el conocer las relaciones que lo ligan, de todas formas hay entre sujeto activo y pasivo una especial relación que debe ser abarcada por el dolo del autor, como un elemento más del tipo. Así entonces, tanto respecto de la conducta, especial relación y resultado, al igual que tratándose del delito de parricidio, se permite una forma de comisión dolosa, ya sea dolo directo o eventual.

Por tanto, es el principio de especialidad ("cuyos fundamentos giran en torno al concepto de 'tipicidad"' 225 ) el que nos ofrece un criterio para determinar cuál de estas dos disposiciones en pugna contempla el hecho en forma total y más exacta. Ya que, si estamos frente a una conducta abarcada en su totalidad por el delito de abandono de personas desvalidas, la consecuencia será la aplicación de esta figura, que contempla una sanción menor para el autor, esto es, la pena de presidio mayor en su grado mínimo, a diferencia de la pena de parricidio que va desde presidio mayor en su grado máximo a presidio perpetuo calificado ${ }^{126}$.

Y las razones para sostener tal solución serían, en primer lugar, el considerar que la conducta de abandonar (como especial forma de dar muerte a una persona) tendría una menor reprochabilidad que los demás casos en que se da muerte a un ascendiente, descendiente o cónyuge. Víctima que por lo demás ya se encontraba enferma o imposibilitada. Decisión legislativa que ciertamente puede criticarse. $Y$ en segundo lugar, porque si dijéramos que tal concurso aparente se soluciona por el principio de alternatividad y

${ }^{124}$ Etcheberry, Alfredo, El concurso aparente de leyes penales (Santiago, Editorial Jurídica de Chile, 1955), p. 46.

${ }^{125}$ Etcheberry, A., El concurso, cit. (n. 124), p. 46.

${ }^{126}$ Principio de especialidad que de igual manera podemos utilizar tratándose de un eventual conflicto entre el delito de abandono de personas y el de homicidio simple en favor del primero (en cuanto se cumpla la descripción típica), por ejemplo, si no se admite la comisión del delito de parricidio con dolo eventual. 
sostenemos la aplicación del delito de parricidio por su mayor penalidad, nunca tendría aplicación el delito de abandono de personas, por encontrarse los elementos del tipo del artículo 352 ya abarcados por las distintas figuras de homicidio.

\section{Lesiones.}

El artículo 352 sanciona el abandono de ciertas personas cuando de ello sigue la causación de lesiones graves, sin distinguir si se trata de lesiones simplemente graves o bien graves gravísimas. Sin embargo, para resolver el eventual concurso aparente consistente en un delito de abandono con resultado de lesiones, la respuesta es la misma para el caso de lesiones simplemente graves del artículo $397 \mathrm{~N}^{\circ} 2$ como para el caso de lesiones graves gravísimas del artículo $397 \mathrm{~N}^{\circ} 1$ CPen. Ello por cuanto en ambos casos las formas de comisión están limitadas a las conductas "berir, golpear o maltratar de obra”. Conductas que han sido consideradas por la doctrina como todas activas, "consistentes en romper la carne o los huesos con un instrumento cortante, dar en el cuerpo del ofendido con uno contundente, o de cualquier modo realizar una acción material que produzca daño en la salud de otro"127.

De ello se sigue que el abandono no podría quedar comprendido en las conductas ya señaladas. Y teniendo presente además las particulares exigencias tanto respecto del sujeto activo como del sujeto pasivo del delito de abandono, tal eventual relación concursal debiese resolverse a favor del delito de abandono de personas por aplicación del principio de especialidad, considerando además que ni la especial relación entre el sujeto activo y pasivo ni la enfermedad o imposibilidad en que se debe encontrar la víctima, son elementos del tipo de lesiones, que es de sujeto indiferente.

Con todo, un eventual concurso podría darse tratándose del abandono de personas desvalidas con resultado de lesiones graves, sean simplemente graves o graves gravísimas en el caso que tales lesiones se cometan abusando de la credulidad o flaqueza de espíritu de la víctima, como es el caso de la especial forma de comisión que prevé el artículo 398 CPen. Ello por cuanto tales hipótesis, que giran en torno a la idea de abuso, pueden fundarse en una relación de dependencia o en una situación de inferioridad psíquica de la víctima, no estando limitadas las formas concretas que puede asumir el abuso.

Caso en el cual, teniendo presente que la especial relación que exige el artículo 352 respecto del autor y la víctima, podría configurar además la agravante que contempla el artículo 400 CPen., referido a la comisión del delito de lesiones simplemente graves o graves gravísimas contra alguna de las

${ }^{127}$ Politoff, S. - Matus, J.-P. - Ramírez, M. C., Lecciones de derecho penal chileno. Parte especial, cit. (n. 55), pp. 136-137. 
personas designadas en el artículo 5 de la Ley No 20.066 de violencia intrafamiliar, entre las cuales se encuentran precisamente el cónyuge, ascendiente o descendiente, llevaría a que la penalidad de esta figura fuera superior a la del abandono de personas desvalidas si se causan lesiones graves gravísimas, ya que en estos casos la pena sería presidio mayor en su grado medio. Sin embargo, el sostener en estos casos la aplicación del artículo 398 por absorción, con la agravante ya señalada, traería aparejado un problema de penalidad, ya que tendría mayor pena el abandonar a una persona causándole lesiones graves gravísimas que abandonar a una persona causando su muerte (pena del artículo 352, esto es, presidio mayor en su grado mínimo). Con todo, puede sostenerse que se trataría de una hipótesis prevista por el legislador, quien no hace diferencia en la penalidad de la figura del artículo 352 para los casos en que el resultado sea la muerte o bien, se cause lesiones graves al ofendido.

\section{Abandono de menores.}

Para resolver los eventuales concursos que pueden surgir entre las figuras del párrafo $₫ 2$ del título $7^{\circ}$, libro II del Código Penal, debemos distinguir tres hipótesis:

i) Abandono de un menor de diez años en un lugar solitario: En esta hipótesis, ante un eventual concurso con el tipo del artículo 352, debe tratarse de un abandono en el cual resulte aplicable la agravante del artículo 348 , esto es, que a consecuencia del abandono resultaren lesiones graves o la muerte del menor, caso en cual, tratándose además de un abandono cometido por las personas designadas en el artículo 347 (padres legítimos o ilegítimos), resultaría aplicable la pena de presidio mayor en su grado medio. En tal evento, coincidimos con De La Fuente, quien señala que "bien podría tratarse de un menor enfermo o incapacitado, en cuyo caso se producirá un concurso aparente -entre la hipótesis de abandono de menores y de personas desvalidas- que tendría que ser resuelto por alternatividad, esto es, aplicando la figura más grave en cada caso, pues no hay razón para beneficiar a quien abandona a un menor por el sólo hecho de encontrarse éste además enfermo o incapacitado, como tampoco hay motivo para rebajar la pena que le correspondería como autor de abandono de su descendiente enfermo en tales condiciones, tan sólo por ser éste además un niño" ${ }^{128}$.

ii) Abandono de un menor de siete años en un lugar no solitario: En esta hipótesis, al igual que el caso anterior, partimos de un abandono con resultado de muerte o lesiones efectuado por aquellas personas designadas en el artículo 347. Caso en el cual la pena aplicable es la de presidio mayor en su grado mínimo, sanción idéntica a la prevista por el legislador para el caso de

${ }^{128}$ De la Fuente, F., cit. (n. 58). 
abandono de una persona desvalida. Por tanto entendemos que de tratarse de un menor enfermo o imposibilitado, tendría aplicación el principio de subsidiaridad tácita, entendiendo que la figura de abandono de personas desvalidas tendría aplicación cuando no se dan las especiales exigencias del abandono de menores, esto es, que se trate de un niño de siete años y que el abandono se realice en un lugar no solitario.

iii) Abandono de un menor de diez años en un lugar no solitario: En este caso estamos frente a una conducta atípica en lo que se refiere a la regulación del delito abandono de menores, por tanto, en el evento que el menor se encuentre enfermo o imposibilitado y sea abandonado por sus ascendientes con resultado de muerte o lesiones, tendría plena aplicación el delito de abandono de personas desvalidas, sin existir concurso alguno que resolver en tal hipótesis.

\section{BIBLIOGRAFÍA}

Beling, Ernst von, Esquema de Derecho Penal. La doctrina del delito-tipo (Análisis de Carlos M. de Elía, Buenos Aires, Librería el Foro, 2002).

Buompadre, Jorge, Derecho penal. Parte especial (2a edición, Buenos Aires, Mario A. Viera, 2003).

Castiñeira Palou, María Teresa, Tema 9. Delitos contra las relaciones familiares, en Silva SÁnchez, Jesús-María (director), Lecciones de Derecho Penal. Parte especial (Barcelona, Atelier, 2006).

Código Penal del Reino de Béljica (Santiago, Imprenta Nacional, 1868).

Cornejo Manrí uez, Aníbal, Derecho Penal (Santiago, Sociedad Editora Metropolitana, 2003).

Creus, Carlos, Derecho penal. Parte especial (6a edición, Buenos Aires, Astrea, 1997), I.

Cury, Enrique, Derecho penal. Parte general ( $8^{\text {a }}$ edición, Santiago, Ediciones Universidad Católica de Chile, 2005).

De la fuente, Felipe, "Abandono de niños y personas desvalidas" (Inédito).

Etcheberry, Alfredo, Derecho penal ( $3^{a}$ edición, Santiago, Editorial Jurídica de Chile, 1998), II.

Etcheberry, Alfredo, Derecho penal ( $3^{a}$ edición, Santiago, Editorial Jurídica de Chile, 1998), IV.

ETCHEBERry, Alfredo, El concurso aparente de leyes penales (Santiago, Editorial Jurídica de Chile, 1955).

Fernández, Pedro Javier, Código Penal de la República de Chile esplicado i anotado (Santiago, Imprenta de la Librería del Mercurio, 1875).

Fontán Balestra, Carlos, Misión de garantía del derecho penal (Buenos Aires, Depalma, 1950).

Garrido Montt, Mario, Derecho penal. Parte especial ( $3^{a}$ edición, Santiago, Editorial Jurídica de Chile, 2007), II.

Garrido Montt, Mario, Derecho penal. Parte general ( 3 a edición, Santiago, Editorial Jurídica de Chile, 2003), II. 
GARrido Montt, Mario, El homicidio y sus figuras penales (Santiago, Ediciones Encina, 1976).

Gómez Tomillo, Manuel, Protección jurídico penal de las personas mayores frente al abandono, especial consideración de los delitos de los Arts. 226,229, 230, de la falta del artículo 619 CP y de sus relaciones concursales, en Revista de Derecho penal y Criminología, $3^{a}$ época, 4 (2010), pp. 175-198.

Iellin, Dalia - Pacheco y Miño, Julio, Capitulo VI. Abandono depersonas, en D’Alessio, Andrés José (director), Código Penal comentado y anotado. Parte especial (Buenos Aires, La Ley, 2004).

Labatut Glena, Gustavo, Derecho Penal (7a edición, Santiago, Editorial Jurídica de Chile, 1983), II.

Labatut Glena, Gustavo, Derecho Penal (9a edición, Santiago, Editorial Jurídica de Chile, 1990), I.

Mapelli CafFARENa, Borja, Estudio jurídico-dogmático sobre las llamadas condiciones objetivas depunibilidad (Madrid, Centro de Publicaciones del Ministerio de Justicia, 1990).

Martínez Guerra, Amparo, Sección 3 ${ }^{a}$. Del abandono de familia, menores o incapaces, en Rodríguez Ramos, Luis (director), Código Penal comentado y con jurisprudencia (3a edición, Madrid, La Ley, 2009).

Mendes de Carvalho, Érika, Las condiciones de procedibilidad y su ubicación sistemática. Una critica al sistema integral del derecho penal, en Revista Electrónica de Ciencia Penal y Criminologia, 24 (2005) 7, p. 10 [visible en internet: http://criminet.ugr.es/ recpc/07/recpc07-10.pdf]

Muñoz Conde, Francisco, Derecho penal. Parte especial (16 edición, Valencia, Tirant Lo Blanch, 2007).

Politoff, Sergio - Grisolía, Francisco - Bustos, Juan, Derecho penal chileno. Parte especial. Delitos contra el individuo en sus condiciones fisicas (2a edición, Santiago, Editorial Jurídica de Chile, 2001).

Politoff, Sergio - Matus, Jean-Pierre - Ramírez, María Cecilia, Lecciones de derecho penal chileno. Parte especial (2a edición, Santiago, Editorial Jurídica de Chile, 2005).

Rivacoba, Manuel de, Código Penal de la República de Chile y actas de las sesiones de la comisión redactora (Valparaíso, EDEVAL, 1974).

Roxin, Claus, Derecho penal. Parte general (2a edición, Civitas, 1997), I.

Sepúlveda Soto, María Eugenia, Las relaciones de familia y su influencia en la responsabilidad penal (memoria de prueba para optar al grado de licenciado en la Facultad de Ciencias Jurídicas, Políticas y Sociales de la Universidad Católica de Chile, 1966).

Silva Sánchez, Jesús María, El delito de omisión: concepto y sistema (Montevideo, B de F, 2003).

Soler, Sebastián, Derecho penal argentino (4a edición, Buenos Aires, Huknos Airks, 1992).

Soria, Juan Manuel, La omisión en el sistema penal: Relación entre las figuras de homicidio y abandono de personas (Buenos Aires, Cathedra Jurídica, 2009).

Soto PiÑeiro, Miguel, La apropiación indebida (Santiago, Editorial Jurídica ConoSur, 1994).

Strafgesetzbuch, 1998 (traducción de Claudia López Díaz, Bogotá, Universidad Externado de Colombia, 1999).

STRUENSEe, Eberhard, Exposición y abandono depersonas, en Jakobs, Günther - STRUENSEE, Eberhard, Problemas capitales del derecho penal moderno ("Prólogo" y "Presentación" de Marcelo A. Sancinetti, Buenos Aires, Hammurabi, 1998).

Welzel, Hans, Derecho penal. Parte general (Buenos Aires, Depalma, 1956). 